\title{
ОРГАНІЗАЦІЯ РОБОТИ МЕДИЧНОЇ СЕСТРИ З ВІЛ-ІНФІКОВАНИМИ ПАЦІЄНТАМИ
}

\author{
Т. О. Кордис, О. П. Мялюк, М. І. Марущак, І. В. Бушинська \\ ДВНЗ «Тернопільський державний медичний університет \\ імені І. Я. Горбачевського МОЗ Украӥни" \\ Рівненський державний базовий медичний коледж
}

\begin{abstract}
У статті проаналізовано роль медичної сестри у забезпеченні догляду за ВІЛ-інфікованими пацієнтами. Показано, що катастрофічне поширення вірусу імунодефіциту людини зумовлює необхідність чіткої організації роботи медичного персоналу з ВІЛ-інфікованими пацієнтами, що обгрунтовує потребу підвищення рівня знань медичної сестри у даній галузі медичної науки. Медичним сестрам постійно потрібно пам'ятати, що контингент з яким вони працюють це люди 3 тяжким хронічним захворюванням не тільки медичного, а й психологічного характеру. Необхідно бути дуже уважними, ретельно виконувати всі алгоритми, використовувати всі деонтологічні надбання медичної науки і постійно підвищувати свій рівень знань.
\end{abstract}

\section{ORGANIZATION OF THE NURSES’ WORK WITH HIV-INFECTED PATIENTS}

\author{
T. O. Kordys, O. P. Mialiuk, M. I. Marushchak, I. V. Bushynska \\ I. Horbachevsky Ternopil State Medical University \\ Rivne Medical College
}

\begin{abstract}
The article analyzes the role of a nurse in providing care for HIV patients. It has been shown that the catastrophic spread of the human immunodeficiency virus necessitates a clear organization of medical staff work with HIVinfected patients, which substantiates the need to increase the level of knowledge of the nurse in the field of medical science. Medical nurses must constantly remember that the contingent they work with is people with severe chronic illness, not only medical but also psychological pathology. It is necessary to be very attentive, carefully carry out all algorithms, to use all deontological achievements of medical science and to constantly raise your level of knowledge.
\end{abstract}

Вступ. Незважаючи на досягнуті успіхи, ВІЛінфекція залишається національною загрозою для багатьох країн світу і всього світового співтовариства на глобальному рівні, а боротьба з вірусом, що викликає це захворювання - одним із найактуальніших завдань, що стоять перед сучасними вченими. Катастрофічне поширення вірусу імунодефіциту людини (ВІЛ) в кінці XX століття призвело до того, що це захворювання набуло розмірів пандемії. За даними ЮНЕЙДС, станом на грудень 2014 р. пандемія ВІЛ-інфекції, починаючи $з 1981$ р., забрала життя більше 39 млн осіб і ще близько 35 млн людей на сьогодні інфіковані ВІЛ [1]. При цьому, за даними Європейського бюро ВООЗ, ВІЛ-інфекція залишається однією з головних проблем в Європейському регіоні, а в Східній Європі триває розвиток епідемії найшвидшими темпами в світі: у той час як на глобальному рівні число нових випадків

(ㄱ Т. О. Кордис, О. П. Мялюк, М. І. Марущак, І. В. Бушинська, 2017
ВІЛ-інфекції скорочується, в країнах Східної Європи і Центральної Азії воно продовжує зростати. Десятки мільйонів людей хворі на ВІЛ-інфекцію. Щорічно приріст нових випадків захворювання становить у світі близько 20 \%, в окремих регіонах - до 44-55 \%. У зв'язку з цим, набуває особливої актуальності проблема профілактики вогнищ ВІЛ-інфекції [2].

Метою дослідження було проаналізувати роль медичної сестри у забезпеченні догляду за ВІЛінфікованими пацієнтами.

Основна частина. У західноєвропейських країнах і Америці сестринський процес (процес догляду за пацієнтами) являє собою метод організації та практичного виконання медичною сестрою своїх обов'язків з обслуговування пацієнтів. Він несе нове розуміння ролі медсестри в практичній охороні здоров'я, вимагаючи не тільки наявності технічної підготовки, а й вміння творчо ставитися до догляду за пацієнтами, індиві- 
дуалізувати і систематизувати догляд. Сестринський процес поділяють на п'ять етапів: збір інформації про стан здоров'я пацієнта; сестринська діагностика; планування; реалізація; оцінка ефективності наданого догляду та корекція догляду в разі потреби [3].

Що стосується ВІЛ-інфекції - це суспільне явище, що має яскраво виражені соціальні та поведінкові характеристики. Медичні сестри навчають населення як запобігти поширенню інфекції, беруть участь в лікуванні, допомагають дотримуватися необхідного режиму та полегшують страждання хворих, надаючи їм психологічну або іншу підтримку, яка залежить від конкретних потреб кожного хворого, а також соціальну підтримку сім'ям, які мають ВІЛ-інфікованих. ВІЛ-інфекція характеризується складним комплексом фізичних проявів: ураженнями тіла, порушенням розумових здібностей, ослабленням духу хворого [4]. Можливість розвитку медикаментозної стійкості ВІЛ ще більш ускладнило організацію догляду за ВІЛ-інфікованими. Якщо на етапі виявлення ВІЛ-інфекції та призначення антиретровірусної терапії хворий здебільшого активно спілкується з лікарем, то в проведенні лікування основна роль може і повинна належати медичній сестрі [5]. Причому, варто підкреслити, що несприятливі тенденції основних епідеміологічних показників із ВІЛ-інфекції в нашій країні не залишають ілюзій щодо зростання навантаження на медичних працівників. У таких умовах вони будуть просто не здатні ефективно контролювати хід лікування хворих на ВІЛ-інфекцію, тим більше при довічному прийманні лікарських препаратів. Оскільки у ВІЛ-програмах медичним сестрам відводиться ключова роль, дуже важливо, щоб вони володіли повною інформацією про все, що належить до ВІЛ-інфекції: епідеміологією, етіологією, патогенезом, а також методам виявлення, обстеження, лікування і надання психологічної та соціальної допомоги. якщо медична сестра належним чином поінформована, то вона здатна попередити поширення хвороби, особливо на близьких і родичів хворого [6]. Дуже важливо для медичної сестри знати шляхи передачі ВІЛ-інфекції, серед яких: контакт із кров'ю, випадковий укол голкою (ріжучими інструментами), через слизові оболонки (попадання бризок крові в очі або рот медпрацівника), через пошкоджені ділянки шкіри (при наявності ран, ексудативних уражень шкіри). Медсестра має можливість запобігти травми ріжучими та колючими предметами (голками, скальпелями, лезами, бритвами), якщо поводитися з ними обережно і без зайвої метушні. Чим більше маніпуляцій з голками, тим вищий ризик нанесення травми. Тому потрібно намагатися не чіпати голки після їх використання і не надягати на них ковпачки, оскільки це поширена причина нанесення травм голками, не згинати і не ламати голки, ріжучі та колючі предмети не можна передавати з рук у руки, потрібно класти їх у нейтральну зону і потім з неї брати, одноразові ріжучі та колючі предмети після використання викидати в контейнери з пластмаси або металу з дезінфікуючими засобами. Важливо, щоб ці контейнери встановлювали в певних місцях, як можна ближче до місця використання предметів, наприклад, в перев'язочній, процедурній, передопераційній та кімнаті для допоміжного устаткування. При дезінфекції гострі інструменти і голки повинні бути відокремлені від інших інструментів, для миття гострих інструментів необхідно надягати найміцніші рукавички, а під час миття, бути особливо обережними. якщо одні й ті ж випадкові травматичні ситуації виникають частіше ніж двічі, то потрібно переглянути методику виконання процедури. Потрібно ретельно вимити руки і шкіру відразу ж після контакту з рідинами організму - це попереджує передачу інфекції собі та пацієнтам [7]. Дезінфекція рук необхідна лише в надзвичайних випадках, якщо руки несподівано забруднилися кров'ю або виділеннями (дезінфекція проводиться тільки після миття рук). Рекомендується застосовувати спиртові дезінфікуючі розчини для рук, але не можна віддавати перевагу дезінфекції рук використанню одноразових рукавичок і миття рук. Оскільки всі рідини організму потенційно небезпечні, завжди надягати рукавички, прибираючи виділення. Зараженню ВІЛ легко запобігти за допомогою поширених дезінфікуючих засобів, мила і води. До бар'єрних методів запобігання, які фізично перешкоджають проникненню вірусу, належать рукавички, халати, захисні окуляри (шоломи). Робочий одяг необхідно змінювати регулярно і кожен раз після забруднення кров'ю або рідинами організму [8].

На медсестрі лежить велика відповідальність не тільки за здійснення якісного сестринського догляду, а й за навчання хворого і членів його сім'і або людей, які доглядають за хворим, елементам правильного догляду та запобіжних заходів. Особи, інфіковані ВІЛ, можуть приймати відвідувачів і лікуватися, не створюючи небезпеки для інших. Медсестри також зобов'язані зберігати в таємниці відомості про результати лабораторного дослідження і медичного огляду пацієнта, вживати належних заходів обережності для попередження поширення інфекції серед пацієнтів і медичних працівників, бути для свого колективу 
прикладом при наданні хворому необхідної медичної допомоги, доводити до відома окремих осіб і професійних груп реальні факти про ВІЛ [9].

На даний момент існує безліч страхів і міфів, пов'язаних із ВІЛ-інфекцією. Тому важливо, щоб медичні працівники знали, яким чином ВІЛ передається і коли не передається. Це дозволить їм вжити належних заходів профілактики [10]. Для найефективнішого обслуговування хворого весь процес його лікування і догляду повинен координуватися однією і тією ж медичною сестрою, наскільки це можливо в межахії компетенції. Причому, щоб спонукати хворого дотримуватися режиму лікування, служба надання медичної допомоги повинна бути гнучкою і надавати хворим можливість вибирати, де йому зручніше і краще отримувати лікування: на дому, в інфекційному кабінеті або СНІД-центрі. Якщо хворий вважає за краще приймати препарати вдома, то для нього потрібно підібрати кваліфікованого помічника в лікуванні, який здійснюватиме вже безпосереднє спостереження за лікуванням. Таким неоціненним помічником може стати медична сестра при умові, що вона буде навчена техніці спостереження за лікуванням, відповідальна, прийнятна для хворого. Оскільки медичні сестри в силу своєї діяльності найбільш близькі хворим і членам їхніх сімей, саме вони здатні створити найсприятливішу для них атмосферу, що дуже важливо для успіху лікування і контролю. Медсестрі доведеться працювати не тільки з ВІЛ-інфікованими, але і з найближчими родичами пацієнтів, тому потрібно дотримуватися певної обережності, оскільки хворий може зробити з родичів своїх співтоваришів при ухилянні від лікування, особливо, якщо родичі бачать у хворого погіршення внаслідок появи побічних ефектів лікування [11]. Для досягнення цілей догляду медсестрі необхідно заручитися розумінням і підтримкою пацієнта. Для цього потрібно детально обговорити з ним кожен пункт плану сестринської допомоги. Якщо хворий перебуває в термінальній стадії захворювання, і, в зв'язку із загальним тяжким станом, вже не здатний до самостійного існування і самообслуговування, необхідно залучити до догляду його близьких і, при необхідності, навчити їх усім необхідним маніпуляціям із догляду [12].

Проблеми, пов'язані з лікуванням захворювань 3 тривалим перебігом і несприятливим прогнозом, не $\epsilon$ новими для медичної науки і тісно пов'язані з проблемами взаємин медичних працівників і пацієнтів. Однак «особливе» ставлення суспільства до хворих на ВІЛ/СНІД, стигматизація і, найчастіше, дискримінація людей, які живуть з ВІЛ, у тому числі й в медичному середовищі, призводить до несприятливих соціальномедичних наслідків $[13,14]$. Більшість пацієнтів, які звернулися до лікувального закладу за медичною допомогою, концентрують свою увагу саме на ставленні та увазі до них медичних працівників, а особливо медичних сестер, які стикаються з ними найчастіше, саме ці складові багато в чому формують почуття «задоволеності і незадоволеності» якістю медичної допомоги. Якість медичної допомоги розглядається як сукупність властивостей процесу надання медичної допомоги, що сприяють формуванню у пацієнта почуття задоволеності в ході взаємодії з медичними працівниками. У свою чергу, задоволеність - це стан консенсусу, згоди, збігу очікуваного пацієнтом результату взаємодії і того, що відбувається в дійсності [15, 16]. У результаті недостатньої підготовки медичних сестер із проблеми ВІЛ/СНІДу та незнання ними заходів особистої та громадської профілактики нерідко мають місце випадки дискримінації ВІЛ-інфікованих, що виражаються у відмові їм в госпіталізації, надання спеціалізованої медичної допомоги та санітарнокурортного обслуговування [17]. Неоднозначне, часто негативне, ставлення медичних сестер до ВІЛ-позитивних пацієнтів призводить до того, що дана група хворих уникає відвідування «звичайних» лікувально-профілактичних установ, а це, в свою чергу, призводить до обтяження стану пацієнта, зростання інвалідизації і, в кінцевому підсумку, призводить до збільшення матеріальних витрат держави на лікування даної категорії громадян. Мало вивчено ставлення ВІЛ-інфікованих хворих до оточуючих, до своєї хвороби, лікування і медичних працівників, які надають допомогу цій групі пацієнтів, зокрема, середньому медичному персоналу. У вітчизняній літературі $\epsilon$ нечисленні публікації із медико-соціальних проблем ставлення ВІЛ-інфікованих пацієнтів до власного захворювання і лікування. Стигматизація та дискримінація людей, які живуть із ВІЛ/СНІДом, не лише зачіпає життя ВІЛ-позитивної людини, а й також $\epsilon$ перешкодою у подоланні ВІЛ/СНІДу в Україні. Так, за даними досліджень, що були проведені у 2011 р. ВБО «Всеукраїнська мережа людей, які живуть з ВІЛ/ СНІД», показали, що 51 \% людей, які живуть із ВІЛ, стикалися із проявами стигматизації та дискримінації з боку медичного персоналу з причин, що включають ВІЛ-статус. Кожен четвертий респондент зазначив, що ВІЛ-статус був причиною обмежень у доступі до послуг у соціальній або медичній сферах. Дані досліджень також вказують на низький рівень толерантності до 
ВІЛ-позитивних в українському суспільстві. Ряд дослідників [18] рекомендує враховувати тип реагування на хворобу при призначенні специфічного лікування. Однак дуже важливим $є$ детальне вивчення впливу взаємин ВІЛ-позитивних пацієнтів і медичних сестер, як найближчої ланки в лікуванні таких хворих, на формування у них установок на лікування.

Медичним сестрам постійно потрібно пам'ятати, що контингент з яким вони працюють це люди з тяжким хронічним захворюванням не тільки медичного,

\section{СПИСОК ЛІТЕРАТУРИ}

1. Покровский В. В. Эпидемиология и профилактика ВИЧ-инфекции и СПИД / В. В. Покровский. - М. : «Медицина», 2002. - 248 с.

2. Роль сестринского персонала в реализации инновационного направления противодействия эпидемии ВИЧ-инфекции «Антиретровирусная терапия как профилактика» / А. Б. Шемшура, В. Н. Городин, С. В. Зотов [и др.] // Международный журнал экспериментального образования. - 2015. - № 11-6. - С. 1004-1008.

3. Добрецова Е. Спид не спит [сценарий шуточной миниатюры] / Е. Добрецова // Сценарии и репертуар. 2011. - № 10. - С. 69-71.

4. Гуревич К. Г. Профилактика ВИч/СпИДа в детскомолодежной среде [Текст] : учебное пособие для студентов педагогических вузов ; под ред. К. Г. Гуревича, Л. М. Шипицыной. - М., 2006. - 80 с.

5. Бородкина О. И. К вопросу о подготовке социальных работников для работы с ВИЧ-инфицированными / О. И. Бородкина, П. В. Гирченко // Русс. журн. ВИЧ/СПИД и родств. проблемы. - 2001. - Т. 5, № 1. - С. 63-64.

6. Изварина О. В. Относись правильно-относись позитивно. Толерантное отношение к ВИЧ-инфицированным / О.В. Изварина // Теоретические и практические основы деятельности специалиста социальной сферы. - Екб., 2008. - С. 13-17.

7. Предоставление паллиативной помощи людям, живущим с ВИч/СПИДом. Клинический протокол для Европейского региона ВОЗ. Всемирная организация здравоохранения, 2012.

8. Никитина М. А. Роль медицинской сестры в обеспечении ухода за ВИЧ-инфицированными пациентами / М. А. Никитина, О. Ю. Егорова, Г. А. Батракова. - М : РОО «СПИД инфосвязь», 2008.

9. Krebs C. P. Intraprison HIV transmission: An assessment of whether it occurs, how it occurs, and who is at risk / C. P. Krebs, M. Simmons // AIDS Education and Prevention. 2002. - № 14. - P. 53-64. а й психологічного характеру. Необхідно бути дуже уважними, ретельно виконувати всі алгоритми, щоб не стати ВІЛ-інфікованими, використовувати всі деонтологічні надбання медичної науки і постійно підвищувати свій рівень знань в даній галузі медицини [19].

Висновок. Катастрофічне поширення вірусу імунодефіциту людини зумовлює необхідність чіткої організації роботи медичного персоналу з ВІЛ-інфікованими пацієнтами, що обґрунтовує потребу підвищення рівня знань медичної сестри у даній галузі медичної науки.

10. Coogan M. M. Oral lesions in infection with human immunodeficiency virus. Bull World Health Organ / M. M. Coogan, J. Greenspan, S. J. Challacombe // Bull World Health Organ. - 2005 Sep. - № 83(9). - P. 700-706.

11. Вересковская М. А. Синдром эмоционального выгорания у медицинских работников [Текст] / М. А. Вересковская, Л. В. Савищева, Н. П. Шинкевич // Вестник пенитенциарной медицины. - 2005. - № 2. - С. 29-32.

12. Власенко С. С. Поставление другого лица в опасность заражения ВИЧ-инфекцией / С. С. Власенко // Российский следователь. - 2009. - № 12. - С. 23-30.

13. Покровский В. И. Клинические рекомендации. ВИЧ-инфекция и СПИД / В. И. Покровский. - М. : ГЭОТАРМедиа, 2007. - 198 с.

14. Батыров Ф. А. Лечебно-диагностическая помощь больным туберкулезом с ВИЧ-инфекцией в условиях многопрофильной специализированной больницы : автореф. дисс. на соискание уч. степени д-ра мед. наук / Ф. А. Батыров. - М., 2005. - 22 с.

15. D'Cruz O. J. Clinical development of microbicides for the prevention of HIV infection / O. J. D'Cruz, F. M. Uckun // Curr. Pharm. Des. - 2004. - V. 10. - P. 315-336.

16. Влияние случаев ВИЧ-инфекции, связанных с нозокомиальными очагами, на дальнейшее развитие эпидемического процесса / С. Р. Саухат, В. В. Покровский, Д. В. Воронцов [и др.] // Эпидемиология и инфекционные болезни. - 2004. - Т. 4. - С. 16-20.

17. Решетников А. В. Медико-социологический мониторинг : руководство / А. В. Решетников. - М. : Медицина, 2003. - 1048 c.

18. Особенности психического статуса ВИЧ-инфицированных Новгородской области / Т. Н. Ткаченко, Б. Б. Фишман, Ю. И. Буланьков [и др.] // Научно-практический рецензируемый журнал. - 2013. - Т. 5, № 2. - С. 45-52.

19. Яковлева Л. В. Возможности профилактики ВИЧ-инфицирования: библиосоциальный аспект / Л. В. Яковлева // Библиотечное дело XXI век. - 2009. Вып. 1. - С. 200-214. 